\title{
The Optimization Of Bioorthogonal Epitope Ligation Within MHC-I Complexes
}

Joanna B. Pawlak ${ }^{1}$, Brett J. Hos ${ }^{2}$, Michel J. van de Graaff ${ }^{1}$, Otty Megantari ${ }^{1}$, Nico Meeuwenoord ${ }^{1}$, Herman S. Overkleeft ${ }^{1}$, Dmitri V. Filippov ${ }^{1}$, Ferry Ossendorp ${ }^{2}$, Sander I. van Kasteren ${ }^{1^{*}}$

\section{Supplementary Figures}<smiles>N#CCC(N)C(=O)O</smiles><smiles>C#CCC(N)C(=O)O</smiles>

Figure S1: Structures of Aha (1), Pg (2).

\begin{tabular}{|c|c|c|c|}
\hline $\begin{array}{l}\text { Position of } \\
\text { Handle }\end{array}$ & $\begin{array}{l}\text { Peptide } \\
\text { Sequence }\end{array}$ & Peptide Name & Source \\
\hline P1 & PgIINFEKL & $\mathrm{OVA}_{257-264}-\mathrm{Pg}-1$ & Ovalbumin (Gallus gallus) \\
\hline P2 & SPgINFEKL & $\mathrm{OVA}_{257-264}-\mathrm{Pg}-2$ & Ovalbumin (Gallus gallus) \\
\hline P3 & SIPgNFEKL & $\mathrm{OVA}_{257-264}-\mathrm{Pg}-3$ & Ovalbumin (Gallus gallus) \\
\hline P4 & SIIPgFEKL & $\mathrm{OVA}_{257-264}-\mathrm{Pg}-4$ & Ovalbumin (Gallus gallus) \\
\hline P5 & SIINPgEKL & $\mathrm{OVA}_{257-264}-\mathrm{Pg}-5$ & Ovalbumin (Gallus gallus) \\
\hline P6 & SIINFPgKL & $\mathrm{OVA}_{257-264}-\mathrm{Pg}-6$ & Ovalbumin (Gallus gallus) \\
\hline P7 & SIINFEPgL & $\mathrm{OVA}_{257-264}-\mathrm{Pg}-7$ & Ovalbumin (Gallus gallus) \\
\hline P8 & SIINFEKPg & $\mathrm{OVA}_{257-264}-\mathrm{Pg}-8$ & Ovalbumin (Gallus gallus) \\
\hline P1 & AhalINFEKL & $\mathrm{OVA}_{257-264}$-Aha-1 & Ovalbumin (Gallus gallus) \\
\hline P2 & SAhalNFEKL & $\mathrm{OVA}_{257-264}$-Aha-2 & Ovalbumin (Gallus gallus) \\
\hline P3 & SIAhaNFEKL & $\mathrm{OVA}_{257-264}$-Aha-3 & Ovalbumin (Gallus gallus) \\
\hline P4 & SIIAhaFEKL & $\mathrm{OVA}_{257-264}$-Aha-4 & Ovalbumin (Gallus gallus) \\
\hline P5 & SIINAhaEKL & $\mathrm{OVA}_{257-264}$-Aha-5 & Ovalbumin (Gallus gallus) \\
\hline P6 & SIINFAhaKL & $\mathrm{OVA}_{257-264}$-Aha-6 & Ovalbumin (Gallus gallus) \\
\hline P7 & SIINFEAhaL & $\mathrm{OVA}_{257-264}$-Aha-7 & Ovalbumin (Gallus gallus) \\
\hline P8 & SIINFEKAha & $\mathrm{OVA}_{257-264}$-Aha-8 & Ovalbumin (Gallus gallus) \\
\hline P2 & KPgVRFDKL & $\mathrm{OVA}_{55-62}-\mathrm{Pg}-2$ & Ovalbumin (Gallus gallus) \\
\hline $\mathrm{P} 7$ & KVVRFDPgL & $\mathrm{OVA}_{55-62}-\mathrm{Pg}-7$ & Ovalbumin (Gallus gallus) \\
\hline P2 & RPgYVYQGL & VSV $_{52-59}-\mathrm{Pg} 2$ & Vesicular Stomatitis Virus Nucleoprotein \\
\hline P4 & RGYPgGQGL & VSV $_{52-59}-\mathrm{Pg} 4$ & Vesicular Stomatitis Virus Nucleoprotein \\
\hline P7 & RGYVYQPgL & $\mathrm{VSV}_{52-59}-\mathrm{Pg} 7$ & Vesicular Stomatitis Virus Nucleoprotein \\
\hline P2 & SPgIEFARL & $\mathrm{HSV} \mathrm{Gp}_{498-505}-\mathrm{Pg}-2$ & Herpes Simplex Virus GpB \\
\hline P4 & SSIPgFARL & HSV Gp ${ }_{498-505}-\mathrm{Pg}-4$ & Herpes Simplex Virus GpB \\
\hline P7 & SSIEFAPgL & $\mathrm{HSV} \mathrm{Gp}_{498-505}-\mathrm{Pg}-7$ & Herpes Simplex Virus GpB \\
\hline
\end{tabular}

Table S2: Overview of all modified epitope peptides used in this study. 
A)

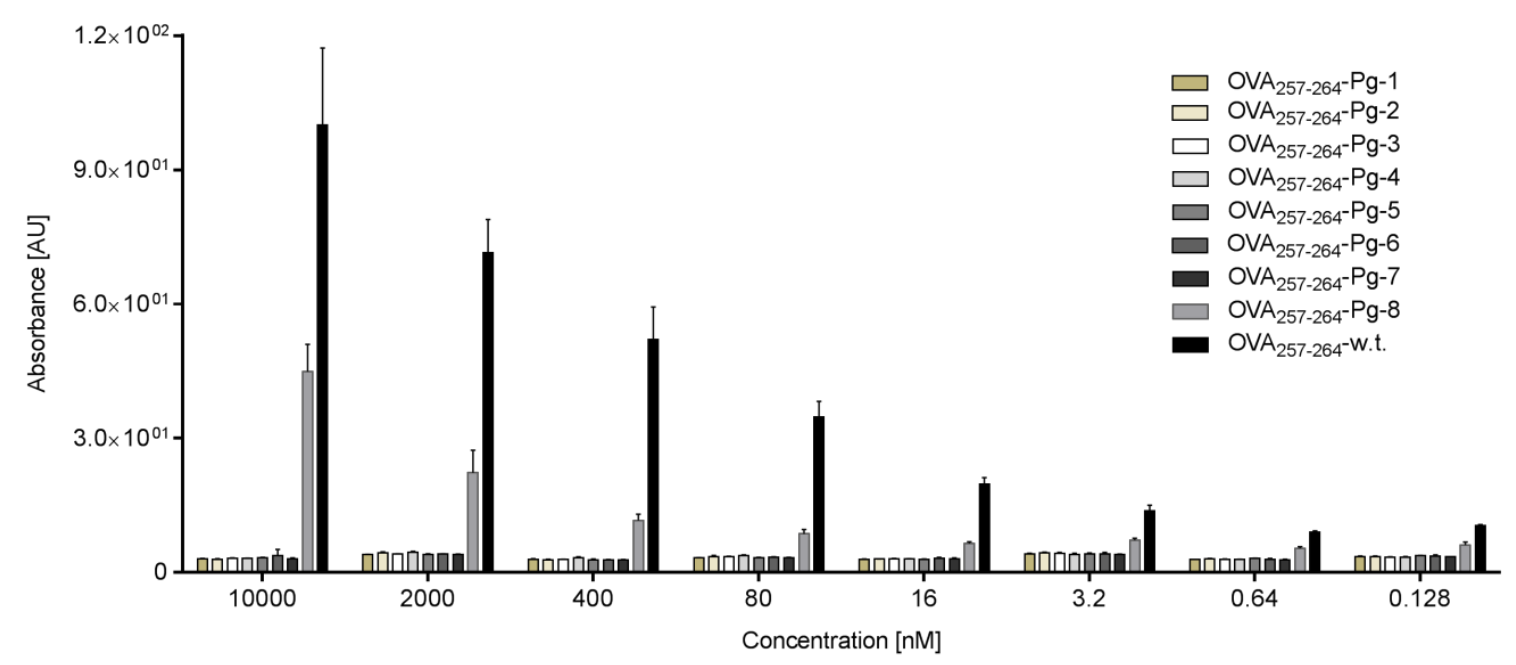

B)

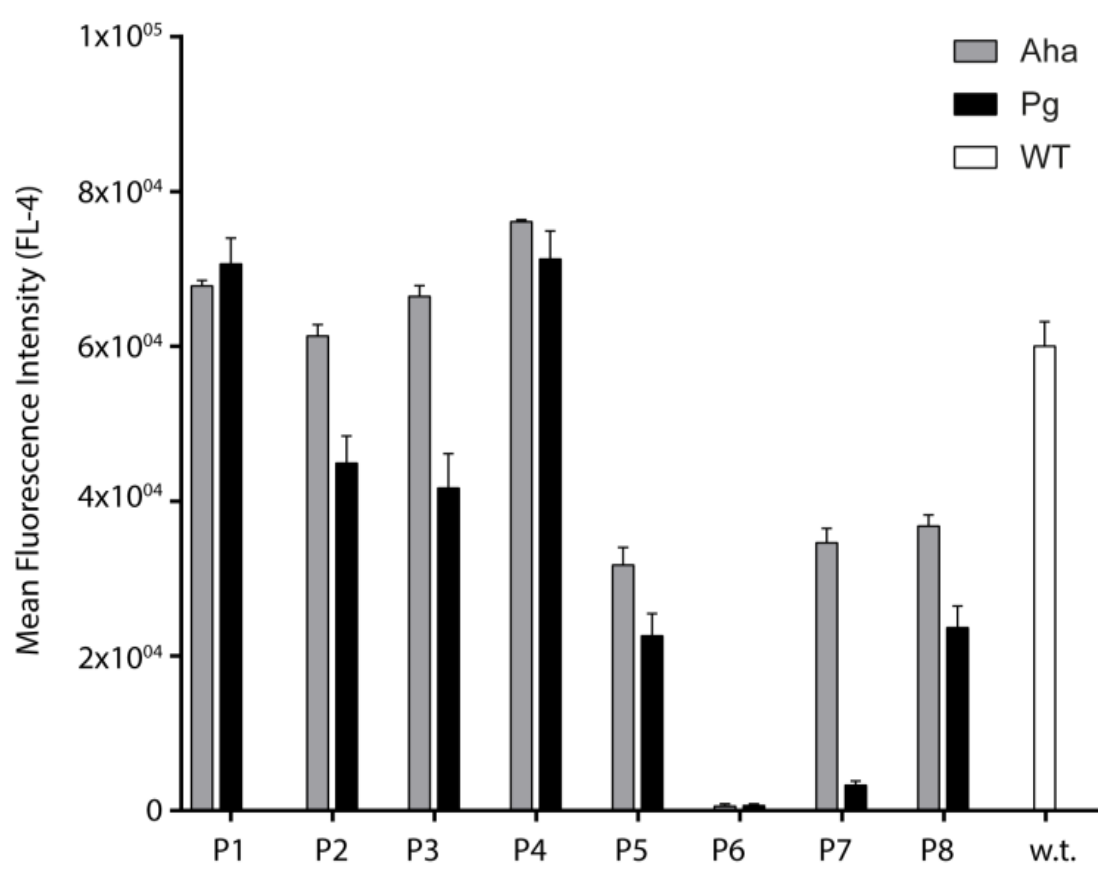

Figure S3: A) Reactivity of biorthogonal antigens with the SIINFEKL-specific T-cell clone B3Z T-cell assay of Pg-modified SIINFEKL. Peptides were serially diluted 1:5 from $10 \mu \mathrm{M}$ and incubated with B3Z using standard conditions ${ }^{l}$. Pg-modified SIINFEKL on the anchor position P8 shows a T-cell response, but no other position does; B) Binding of complex-specific antibody 25-D1.16 to H-2K -bound SIINFEKL analogues on RMA-S cells. 


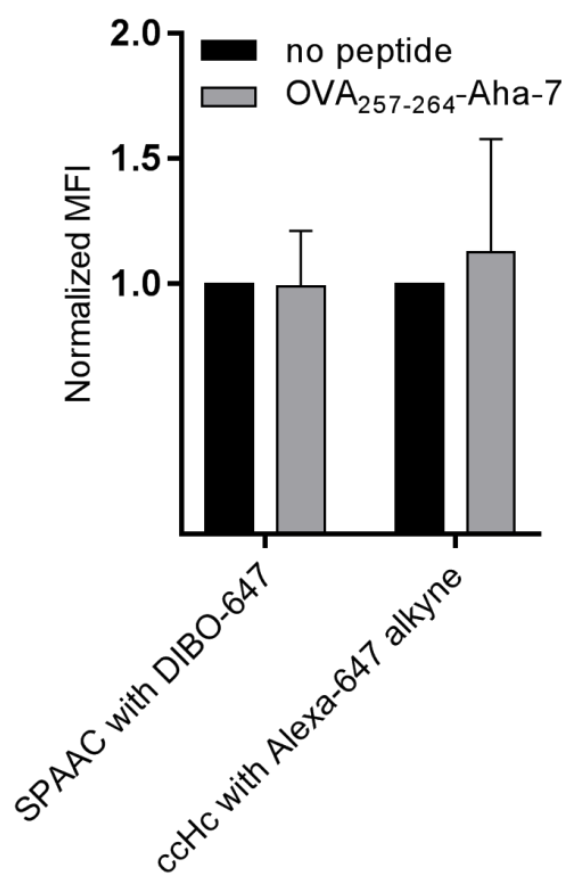

Figure S4: Normalized mean fluorescence intensity (MFI) in FL-4 channel (647 nm) of the strain-promoted azide-alkyne cycloaddition (SPAAC) with Alexa Fluor 647 DIBO Alkyne (DIBO-647) and Copper(I)-Catalyzed Azide-Alkyne Huisgen Cycloaddition (ccHc) with Alexa Fluor-647-alkyne. Both reactions were performed with OVA 257-264-Aha-7 and no peptide as control. Data obtained from experiments were normalized to the corresponding control of each samples, where the control equals 1. All error bars represent the SD of the mean from at least 2 independent experiments. 
A)
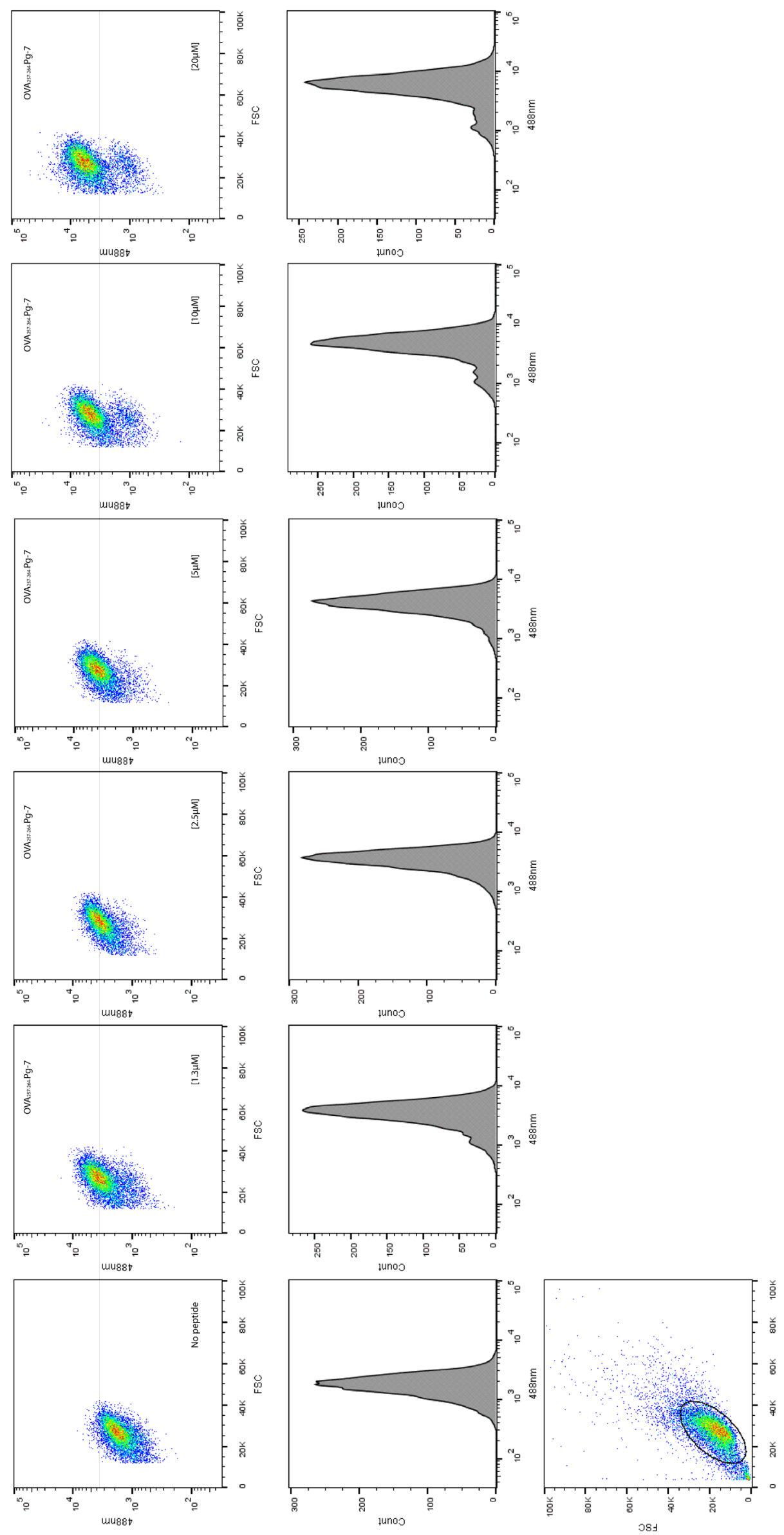
B)
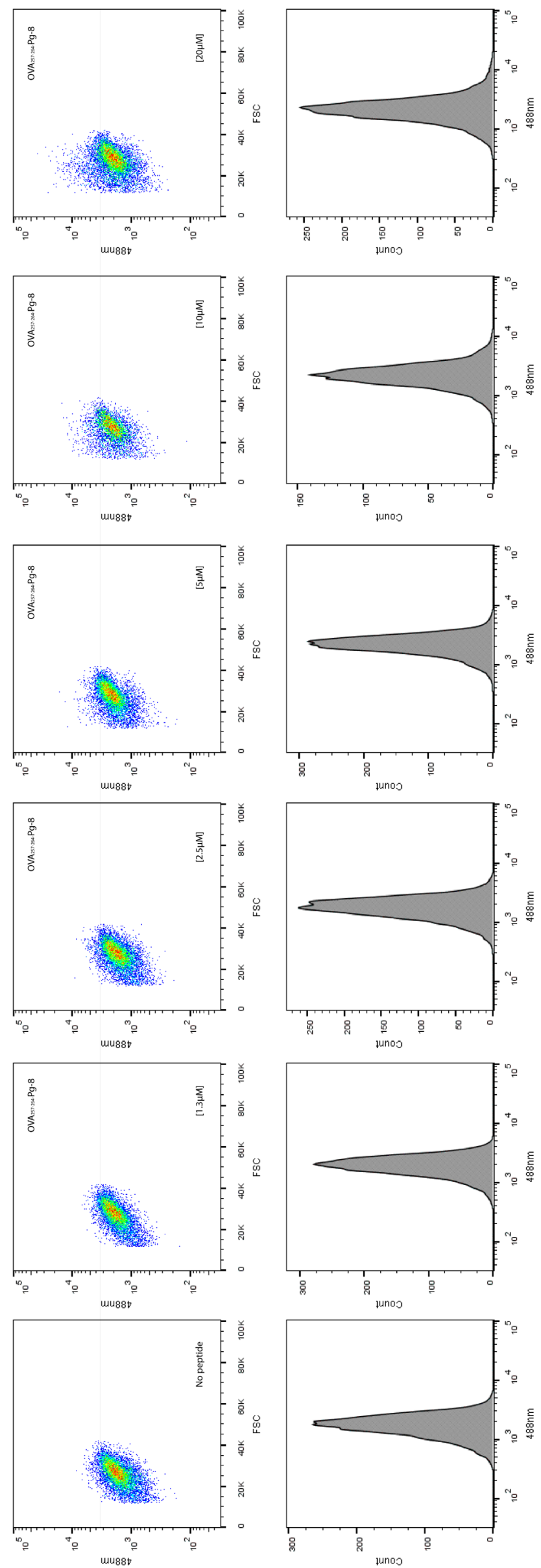
Figure S5: (Previous two pages); Flow cytometry data underpinning Figure 2B: Fluorescence intensity in the FL-1-channel (488 nm) on gated cells was plotted for different peptide concentrations; A) FACS plots of P7modifications; B) FACS plots of P8-modifications.

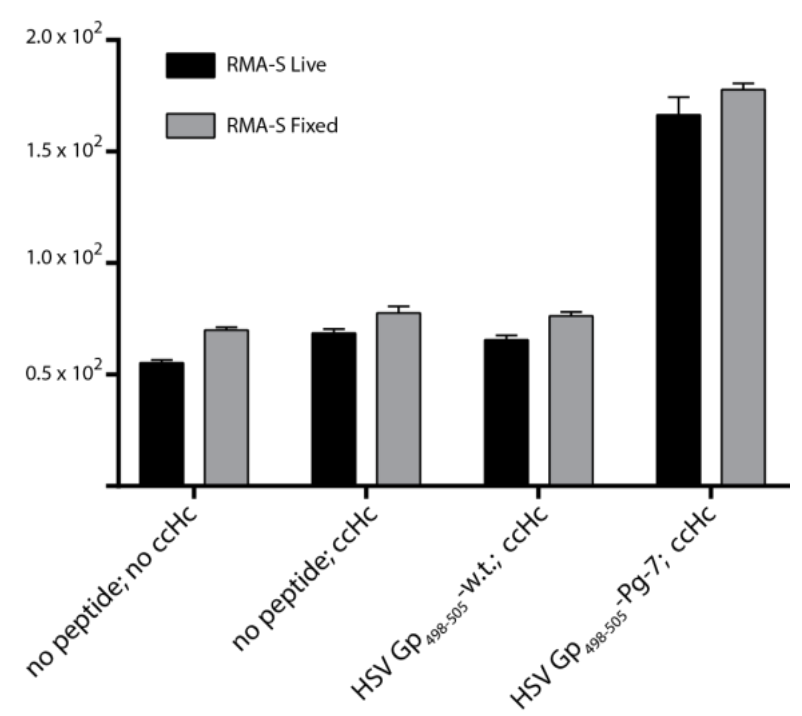

Figure S6: Comparison of ccHc conditions on cells fixed with $0.5 \%$ PFA to ccHc reaction performed on live cells (for these reactions the reaction time was reduced to 15 minutes to prevent permeabilization due to cell

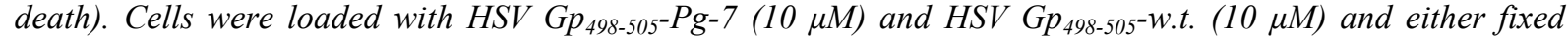
before ccHc, or used under live cell ccHc-conditions. Assay was set up in triplicate with all error bars correspond to $S D$ of the mean.
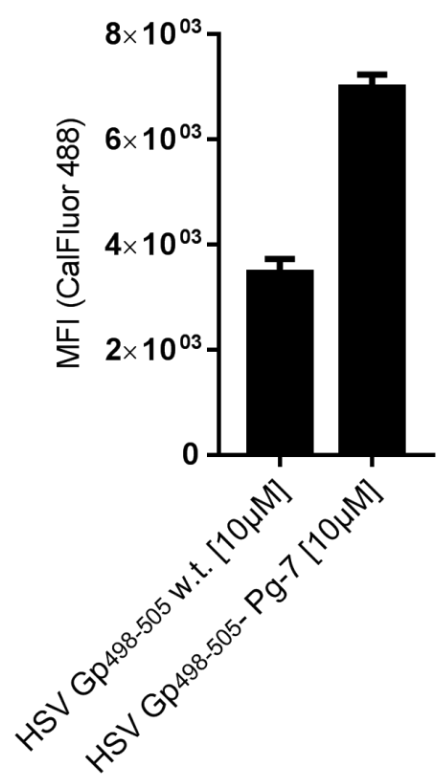

Figure S7: ccHc of HSV Gp $498-505-l o a d e d ~ D 1-c e l l s$. Ligation characteristics were the same as for RMA-S labeling, with HSV Gp ${ }_{498-505}$ w.t. control peptide showing minimal labeling, where the solvent exposed P7 labels strongly. Data obtained from experiments were normalized to the corresponding control of each samples, where the control equals 1. All error bars represent the SD of the mean from 2 independent experiments. 

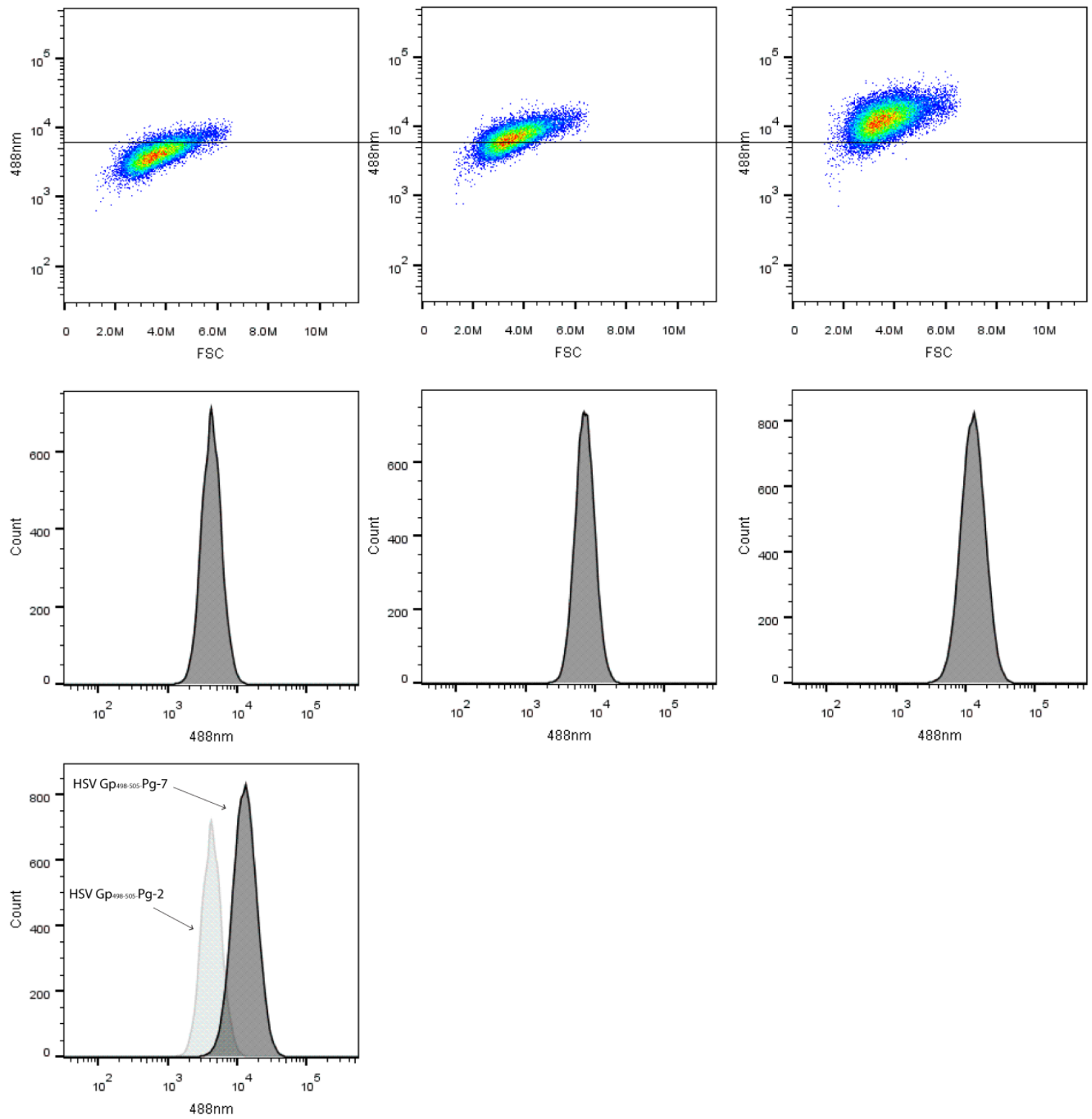

Figure S8: FACS data underpinning Figure 4D. 


\section{Experimental Methods}

\section{General Reagents}

Alexa Fluor 488 Azide (catalogue number: A10266) and all other fluorophores were purchased from Thermo Fisher Scientific. Azidohomoalanine and Propargylglycine-Fmoc were purchased from Anaspec. Tris(3-hydroxypropyl-triazolylmethylamine) (THPTA) was purchased from Sigma-Aldrich, as were all other reagents at the highest available grade. Mouse Anti-Mouse H-2 $\mathrm{K}^{\mathrm{b}}$ (B8-24-3 clone) was made in-house. 25-D1.16-APC conjugated was purchased from eBioscience (Cat. \#: 12-5743-81) (APC conjugated in-house). Secondary antibody (Goat anti-Mouse IgG conjugated to Alexa Fluor-647 (catalogue number: A-21235) was purchased from Thermo Fisher Scientific. All solvents were purchased from Biosolve Ltd. Phosphate buffered saline (PBS) is $5 \mathrm{mM} \mathrm{KH} \mathrm{PO}_{4}, 15 \mathrm{mM} \mathrm{Na}_{2} \mathrm{HPO}_{4}, 150$ $\mathrm{mM} \mathrm{NaCl}, \mathrm{pH} 7.4$.

NMR spectra (1H and $13 \mathrm{C}$ ) were measured on a Bruker $\mathrm{AV}-400 \mathrm{MHz}$ spectrometer at ambient temperature at the Leiden Institute of Chemistry NMR Facility. Chemical shifts are recorded in ppm. Residual solvent peaks were used as an internal standard.

\section{Peptide Synthesis}

All peptides were synthesized using standard Fmoc Solid Support Chemistry and purified using High

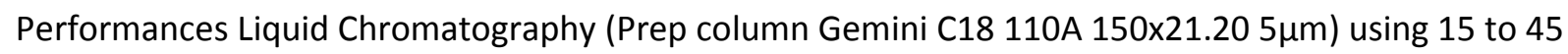
\% gradient (A: 0.1\% TFA in MilliQ H2O, B: ACN). LC-MS measurements were done on an API 3000 Alltech 3300 with a Grace Vydac 214TP 4,6 mm x $50 \mathrm{~mm}$ C4 column and analyzed by electrospray LCMS analysis on a PE SCIEX: API 3000 LC/MS/MS system using a Gemini 3u C18 110A analytical column ( $5 \mu$ particle size, flow: $1.0 \mathrm{ml} / \mathrm{min}$ ), on which the absorbance was also measured at 214 and $254 \mathrm{~nm}$. Solvent system for LC-MS: A: 100\% water, B: 100\% acetonitrile, C: 1\% TFA (aq).

\section{Calfluor-488 Synthesis}

Calfluor-488 was synthesized as described previously ${ }^{2}$.

Analytical data: $\mathrm{M} / \mathrm{z}$ found: $836,3[\mathrm{M}=\mathrm{H}]^{+}$

${ }^{1} \mathrm{H}$ NMR (400 MHz): 


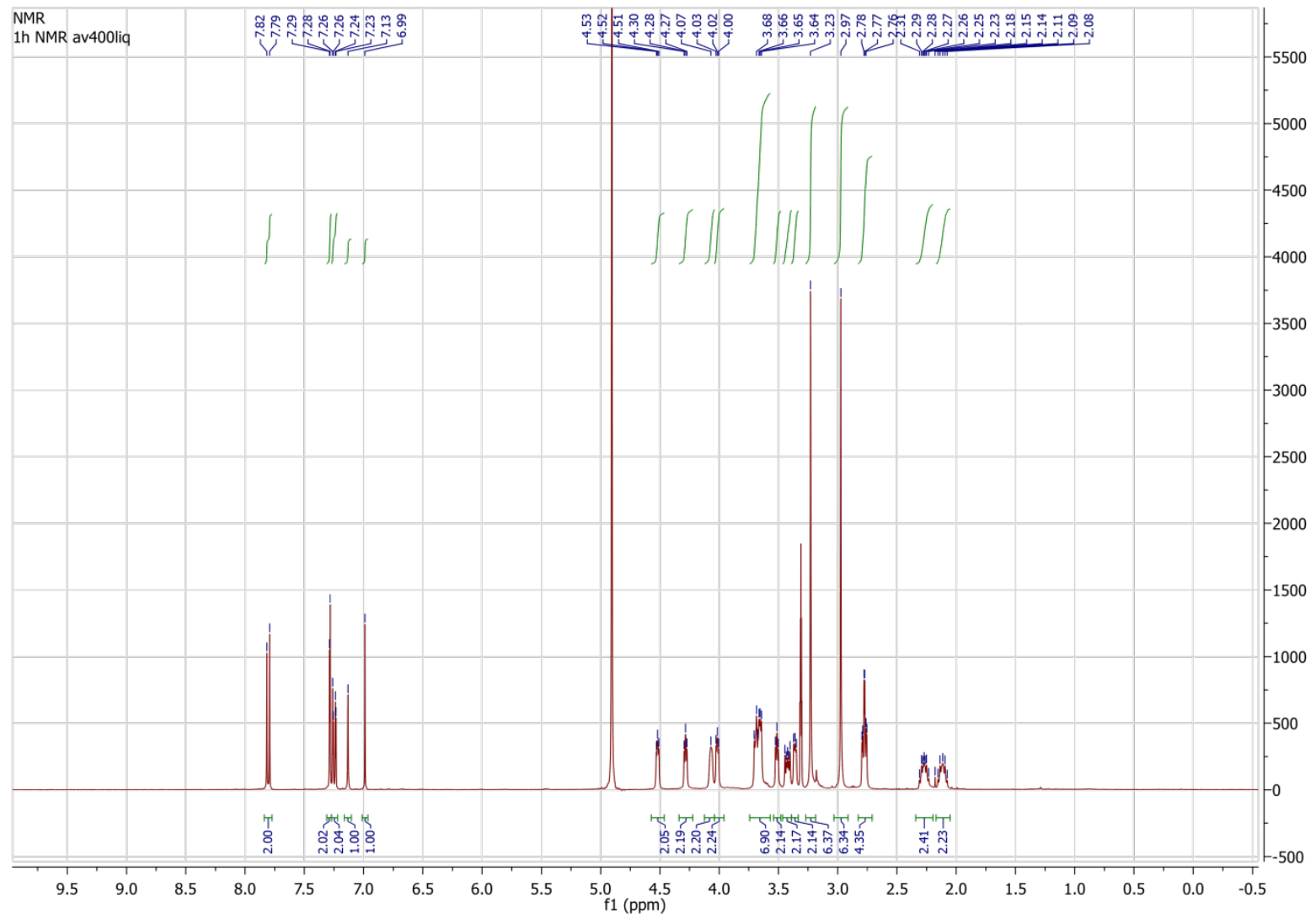

${ }^{13} \mathrm{C}$ NMR (100 MHz):

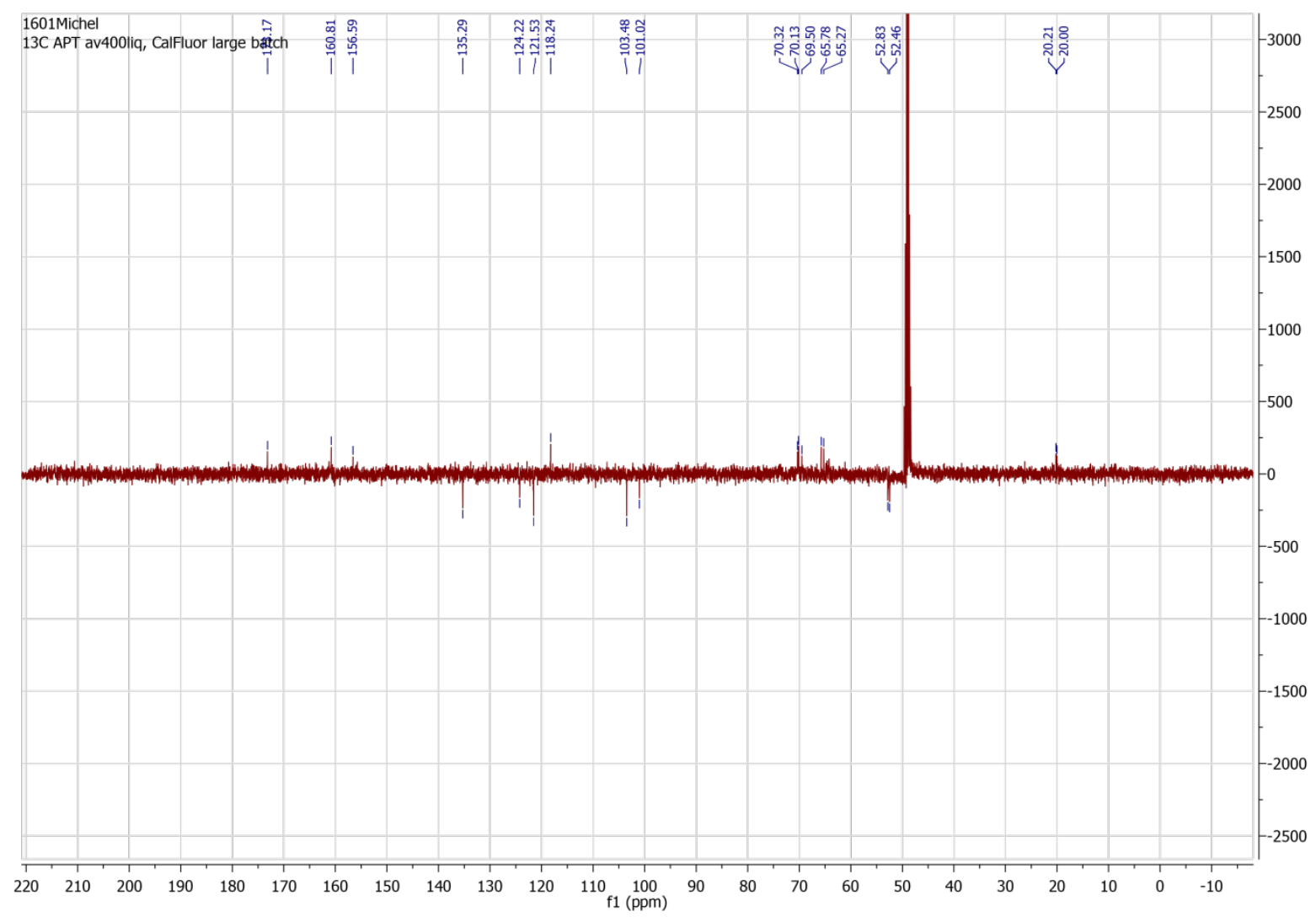


RMA-S MHC I-binding and stability assays

RMA-S assays were essentially performed as described previously, ${ }^{3,4}$. Briefly, RMA-S cells were grown and passaged at $37{ }^{\circ} \mathrm{C}, 5 \% \mathrm{CO}_{2}$ in RPMI-1440 augmented with $10 \% \mathrm{FCS}$ and antibiotics. Prior to the experiment, the incubation temperature was lowered to $26^{\circ} \mathrm{C}$ for 48 hours $\left(10^{6}\right.$ cells $\left./ \mathrm{mL}\right)$ to ensure metastable MHC-I surface expression. For affinity tests, cells were incubated with rescue peptides in serum free medium at the indicated concentrations for 4 hours and washed in protein blocking agent (PBA: $5 \% \mathrm{BSA}$ in PBS $+0.1 \% \mathrm{w} / \mathrm{v} \mathrm{NaN} \mathrm{N}_{3}$ ). For MHC I-peptide complex stability assays, $26^{\circ} \mathrm{C}$ RMA-S cells were pulsed for 1 hour with respective peptides at the indicated concentrations, and washed thoroughly in ice-cold serum free medium, after which they were placed back at $37^{\circ} \mathrm{C}$ and chased for the indicated time. After each timepoint, cells were fixated in $4 \%$ fixation buffer (Cat \#420801, Biolegend) for 30 minutes. After this time, the cells were washed with PBA. Both assays were subsequently stained with anti-Mouse- $\mathrm{H}-2 \mathrm{~K}^{\mathrm{b}}(400 \mathrm{ng} / \mathrm{mL} ;>60 \mu \mathrm{L} /$ well) in PBA for 30 minutes on ice, prior to washing with PBA twice. Secondary antibody (Goat anti-Mouse IgG conjugated to AlexaFluor$647 ; 5 \mu \mathrm{g} / \mathrm{mL}$ ) was added and the cells were again incubated on ice for 30 minutes prior to washing twice with PBA before analysis. Analysis was performed on a BD Accuri ${ }^{\mathrm{TM}}$ C6 Plus Flow Cytometer. All flow cytometry data was analyzed using FlowJo v10.1 (Miltenyi Biosciences).

\section{5-D1.16-binding of bioorthogonal epitopes}

RMA-S cells were incubated with a serial dilution of peptides as above. After the 4 hour loading period and blocking, cells were incubated with 25-D1.16-APC conjugated antibody $(1.3 \mu \mathrm{g} / \mathrm{mL} ;>60$ $\mu \mathrm{L} /$ well, conjugated in-house) $)^{5}$ in PBA for 30 minutes on ice, prior to washing with PBA twice. Cells were analyzed by flow cytometry as described above. Fluorescence intensity in the APC-channel were plotted against peptide concentration at $1 \mu \mathrm{M}$ was used for Fig. S3B.
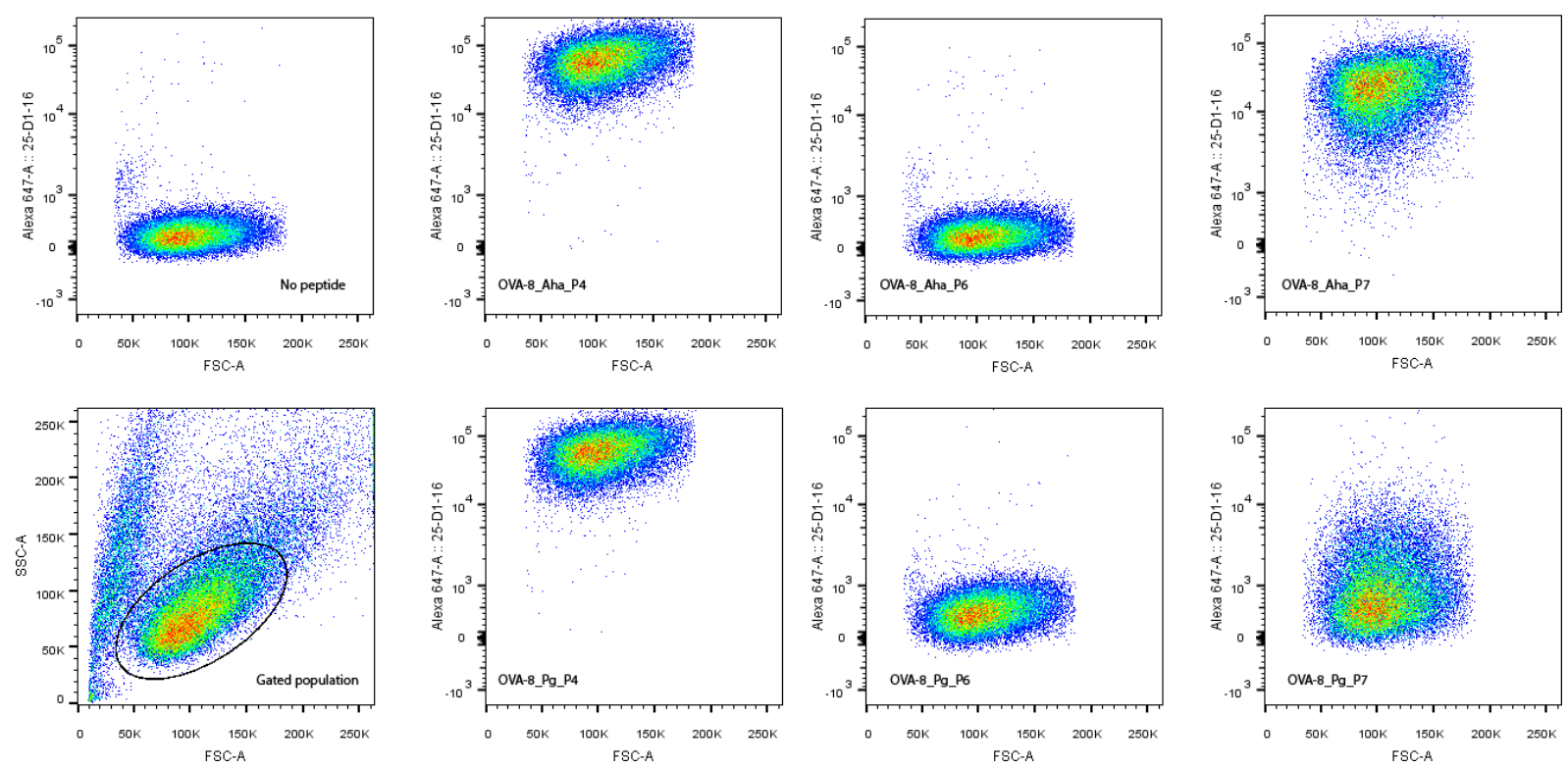

Example of flow cytometry data: the FACS-plots of the 25-D1.16-binding assay. Fluorescence intensity in the APC-channel were plotted against peptide concentration at $1 \mu M$.

\section{Bioorthogonal Modification reactions on RMA-S Cells}

RMA-S Cells were grown and as described above for the binding assay and plated in 96-well v-bottom microtiter plate $\left(400,000\right.$ cells/well) in serum free medium and incubated for $\sim 1 \mathrm{~h}$ at $37^{\circ} \mathrm{C}$ with 
respective peptides at the indicated concentrations. After the incubation the cells were washed twice in PBS and subsequently fixed for 1 hour at RT in 0.5\% PFA in PBS (Cat \#420801, Biolegend; diluted $1: 8$ ) and washed twice more with PBS. Cells were then exposed to the biorthogonal labeling mixture $\left(1 \mathrm{mM} \mathrm{CuSO}_{4}, 10 \mathrm{mM}\right.$ sodium ascorbate, $1 \mathrm{mM}$ THPTA ligand,10 mM aminoguanidine, 100 $\mathrm{mM}$ HEPES, pH 8.4, CalFluor-488 $10 \mu \mathrm{M}$,). After 45 minutes at RT, the reaction mixture was aspirated and the cells were blocked with $1 \%$ BSA and $1 \%$ fish gelatin before being washed twice with PBS prior to analysis by flow cytometry. Assays were set up in triplicate, unless otherwise indicated. The statistical significance of the indicated differences was analyzed by the two-tailed student's t-test with the significance specified using $p$ values with ${ }^{*} p \leq 0.05,{ }^{* *} p \leq 0.01,{ }^{* * *} p \leq 0.001$ and ${ }^{* * * *} p \leq$ 0.0001 . All error bars correspond to SD of the mean.

\section{Reactivity of bioorthogonal SIINFEKL peptides in a B3Z T-cell assay}

RMA-s cells were grown as described above and plated in 96-well tissue-culture treated microtiter plate $\left(50,000\right.$ cells/well) and incubated for $1 \mathrm{~h}$ at $37^{\circ} \mathrm{C}$ with SIINFEKL modified peptides at the indicated concentrations, followed by a wash with complete IMDM. After the wash, the T-cell hybridoma B3Z cells (50,000 cells/well) were added. The RMA-s and T-Cells were co-cultured for $17 \mathrm{~h}$ at $37^{\circ} \mathrm{C}$. Stimulation of the B3Z hybridoma was measured by a colorimetric assay using CPRG (chlorophenol red- $\beta$-D-galactopyranoside) as a substrate as described ${ }^{6}$.

\section{Competition assay with unlabeled peptide}

RMA-S cells were grown and treated as described above for the bindings assay, prior to loading. Incubation of RMA-S cells with HSV-Gp $p_{498-505}-\mathrm{Pg} 7$ epitopes was performed for 4 hours at $4 \mu \mathrm{M}$, in presence of increasing amounts of w.t. HSV-Gp $p_{498-505}$ at the indicated concentrations. The amount of peptide in all samples was equalized to $36 \mu \mathrm{M}$ by adding the lacking amount of adenoviral $\mathrm{H}-2 \mathrm{D}^{\mathrm{b}}$ binding epitope of the human Adenovirus $5 \mathrm{E} 1 \mathrm{a}$ protein $\mathrm{Ad} \mathrm{O}_{234-243}{ }^{7}$. Bioorthogonal ligation was subsequently performed as described above.

\section{References:}

[1] Karttunen, J., and Shastri, N. (1991) Measurement of ligand-induced activation in single viable T cells using the lacZ reporter gene, Proc. Natl. Acad. Sci. U.S.A. 88, 3972-3976.

[2] Shieh, P., Dien, V. T., Beahm, B. J., Castellano, J. M., Wyss-Coray, T., and Bertozzi, C. R. (2015) CalFluors: A Universal Motif for Fluorogenic Azide Probes across the Visible Spectrum, J. Am. Chem. Soc. 137, 7145-7151.

[3] Ljunggren, H.-G., Stam, N. J., Ohlen, C., Neefjes, J. J., Hoglund, P., Heemels, M.-T., Bastin, J., Schumacher, T. N. M., Townsend, A., Karre, K., and Ploegh, H. L. (1990) Empty MHC class I molecules come out in the cold, Nature 346, 476-480.

[4] Feltkamp, M. C., Smits, H. L., Vierboom, M. P., Minnaar, R. P., de Jongh, B. M., Drijfhout, J. W., ter Schegget, J., Melief, C. J., and Kast, W. M. (1993) Vaccination with cytotoxic T lymphocyte epitope-containing peptide protects against a tumor induced by human papillomavirus type 16-transformed cells, Eur. J. Immunol. 23, 2242-2249.

[5] Porgador, A., Yewdell, J. W., Deng, Y., Bennink, J. R., and Germain, R. N. (1997) Localization, Quantitation, and In Situ Detection of Specific Peptide-MHC Class I Complexes Using a Monoclonal Antibody, Immunity 6, 715-726.

[6] Khan, S., Bijker, M. S., Weterings, J. J., Tanke, H. J., Adema, G. J., van Hall, T., Drijfhout, J. W., Melief, C. J. M., Overkleeft, H. S., van der Marel, G. A., Filippov, D. V., van der Burg, S. H., and Ossendorp, F. A. (2007) Distinct uptake mechanisms but similar intracellular processing of 
two different toll-like receptor ligand-peptide conjugates in dendritic cells, J. Biol. Chem., M701705200.

[7] Neisig, A., Roelse, J., Sijts, A. J., Ossendorp, F., Feltkamp, M. C., Kast, W. M., Melief, C. J., and Neefjes, J. J. (1995) Major differences in transporter associated with antigen presentation (TAP)-dependent translocation of MHC class I-presentable peptides and the effect of flanking sequences, J. Immunol. 154, 1273-1279. 